\title{
WILEY

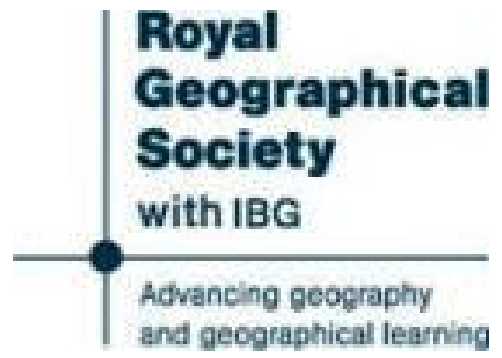

The Exploration of Tibesti, Borkou, and Ennedi in 1912-1917: A Mission Entrusted to the Author by the French Institute: Discussion

Author(s): Henry McMahon, Viscomte de la Panouse, Harry Johnston and Hanns Vischer Source: The Geographical Journal, Vol. 56, No. 4 (Oct., 1920), pp. 263-267

Published by: geographicalj

Stable URL: http://www.jstor.org/stable/1781651

Accessed: 27-06-2016 02:51 UTC

Your use of the JSTOR archive indicates your acceptance of the Terms \& Conditions of Use, available at

http://about.jstor.org/terms

JSTOR is a not-for-profit service that helps scholars, researchers, and students discover, use, and build upon a wide range of content in a trusted digital archive. We use information technology and tools to increase productivity and facilitate new forms of scholarship. For more information about JSTOR, please contact support@jstor.org.

Wiley, The Royal Geographical Society (with the Institute of British Geographers) are collaborating with JSTOR to digitize, preserve and extend access to The Geographical Journal 
of colonial jewels France may well find a place for arid Borkou and the barren Tibesti. For would it not seem that they are, in some sort, talismans, and that when Gaul and German grapple on the banks of the great river that was set by nature and destiny to hold them apart, Fortune, that wayward goddess, shall give victory to whichever country has a son exiled in those mysterious regions, seeking, by rock and desert, new ways across their ancient sand?

\section{[Translated from the French by $W . G$. Tweedale, M.A., Oxon.]}

Before the paper the PRESIDENT said: It is a special pleasure to us to welcome here this evening that well-known French explorer and geographer, Colonel Tilho. We had been long hoping to have the pleasure of receiving him and of hearing an account of his recent journeys from 1912 to 1917 , but owing to the press of official business he was not able to come here in the summer, and it is only by the greatest good fortune, and by the exercise of a little tactful pressure upon the different Governments, that he has been able to be present this evening. This is not the first occasion upon which he has been before the Society. He gave us a most interesting paper about ten years ago, so that he is not a stranger, and we are very glad to welcome him again. What he will describe to us this evening will be his journeys in Central Africa and the French Sudan between the years 1912 and 1917 ; and it was for the valuable work which he did during those journeys and for his general contribution to geographical knowledge that we awarded him, two years ago, our Patron's Gold Medal. I have, therefore, very great pleasure in introducing Colonel Tilho to you and asking him now to address us.

\section{Colonel Tilho then gave in French a summary of the paper printed above, and $a$ discussion followed.}

The PResident (after the paper): Sir Henry McMahon, who was High Commissioner in Egypt during part of the war, is present here, and we shall be very glad if he will kindly make some observations in regard to Colonel Tilho's interesting lecture.

Colonel Sir Henry MCMAHON : We are much indebted to Colonel Tilho for a most interesting paper to-night. It is not only of very great interest, but a valuable contribution to geographical knowledge. I will leave the discussion of the lecture as regards its geographical and cartographical aspect to others, but there is one portion of the paper to which I should like to call your attention. As Colonel Tilho has told you, during the war the Germans and Turks got a footing in Tripoli. He has told you how Enver Pasha's brother, Nuri Bey, landed on that coast, and with him many Germans. Their object was to get into touch with the Senussi ; raise the whole country against us through the Senussi influence, and threaten our western flank both in Egypt and the Sudan. They very nearly succeeded ; and if our brave allies, the French, had not forestalled them in the country described to-night, they would undoubtedly have established themselves there. It is a valuable objective as being the first place in which water and supplies can be got after leaving the oasis of Kufra. We will imagine for one moment that they had established themselves there. You can at once see what a dangerous focus of intrigue and unrest, what a source of danger it would have been on our flank all along our western front. Having forestalled the enemy there, no further trouble ensued, but our friend the Sultan of Darfur, who misjudged the time of the Senussi arrival and 
counted too confidently on their aid, had already started hostilities with us, and a war ensued which in times of peace would have attracted wide prblic attention. but in the days when our interest was so concentrated on other ronts it almost escaped notice. Suffice to say that by a brilliant series of military operations, our troops, under the direction of Sir Reginald Wingate, the Sirdar of the Sudan, drove him out of his capital and took the whole of his country. If the Senussi had at this time been established with their German and Turkish assistants on our flank, it might have been a very different job indeed. I look upon this incident as an object lesson of the good that co-operation can effect in a work of this kind, and it is, I hope, not only an object lesson of what has been done in the past times of war, but an augury of what we can do and should do between us in the future times of peace. As Colonel Tilho has explained to you, co-operation is essential for the development of this great country of Africa, and I trust that it will be the guiding principle of our two great nations not only in the development of that country, but in furthering the welfare of the backward peoples placed under our guardianship.

The PRESIDENT : The French Military Attaché is present and we should be very pleased if he would kindly address us.

General the VIsCOMTE DE LA PANOUSE: Je ne savais pas que j'aurais à prendre la parole ce soir en sorte que je me trouve un peu pris au dépourvu. Je vous demanderais donc la permission de m'exprimer en Français. Il y a quelques vignt ans, il eut été impossible de discuter ici dans une atmosphère de calme et de confiance mutuelle une question relative au centre du Continent Africain. Heureusement depuis cette époque, grâce aux bienfaisants accords de 1904, les malentendus entre le Royaume Uni et la France se sont dissipés, l'Entente Cordiale est née, elle s'est développée et elle a vu son couronnement dans une alliance militaire étroite et loyale pendant la plus grande guerre que le monde ait vue. Le Colonel Tilho vous a exposé pourquoi dans le développement économique de ce Grand Centre Africain, l'action unie des deux grandes Nations est nécessaire sous peine d'aboutir à un gaspillage inutile d'efforts et d'argent. Mais je vois aussi une autre raison pour laquelle nous devons travailler ensemble; l'Empire Britannique et la France ont lutté pendant cette grande guerre pour faire triompher les principes du droit et de la liberté contre l'oppression et la barbarie. Notre victoire nous a créé des obligations et en particulier celle de défendre les populations noires contre la tyrannie des marchands d'esçlaves et de l'oppression des sectes musulmanes et de leur donner le bien-être auquel a droit tout être humain. Ce devoir ne sera utilement rempli que si nos nations s'entendent sur les mesures à prendre et les réalisent en commun. La belle œuvre d'humanité à accomplir sera ainsi un nouveau lien entre les deux Grandes Puissances qui se partagent le continent Africain.

The PREsident : We have been fortunate to catch Sir Harry Johnston. $\mathrm{He}$ is one of our greatest authorities upon Africa generally, both Central and Northern. We should be very glad if he would make some remarks.

Sir HARRY JOHNSTON: I had the honour some years ago, just after the war had started, of showing you a somewhat similar map of Africa with railways designed on it partly by my own fancy, and I may say to a great extent by following French fancies too ; for about that time I had been in the north of Africa, and had been allowed to pursue for a certain distance the tracing of the projected trans-Saharan railway, the progress of which was only stopped by the war. I conceived then the idea that it was of the highest importance to Western Europe that that line should be made, though I, like most of you, did not appreciate the influence on affairs that the submarine 
would have ; but of course that conviction has been strengthened by the events of the war. Had we had the trans-Saharan railway in existence during the war we should not have suffered as much as we did from the loss of some of the most important materials for our industries caused by the interruptions of the sea routes, the destruction of steamers, etc. It is a matter of absolute necessity, I consider, that that trans-Saharan line should be made to link up the valley of the Niger with French North Africa, and further with Western Europe; because, as Colonel Tilho has pointed out, the channel between Tangier and the Spanish coast could be easily patrolled and kept free of submarines, and even crossed by train ferries. Then another point I should like to raise is as to the further exploration of those Tibesti highlands and the lofty plateaus that are connected with them on the north-west and south-east. Colonel Tilbo did not mention in his discourse what he said to me privately, that he had found in some parts of that region, possibly Borku, fossilized bones of elephants. He has referred to the native legends and to the drawings on the rocks which point to the existence of hippopotami in regions now entirely devoid of surface water. He showed some of these engravings. They are very similar to rock drawings which can be traced right across the Sahara desert, exhibiting a fauna now completely passed away. One reason why Tibesti should be explored is, that we might find there the fossil and semi-fossil remains of a very extensive tropical African fauna, because that isthmus of high land between the south of Tunis on the north, and Darfur and the regions round Lake Chad on the south, seems to have been the principal route by which the fauna of Miocene and Pliocene Europe and the Mediterranean basin reached Tropical Africa. There are more and more indications that the Sahara desert to the west and the Libyan and Nubian deserts to the east were formerly under water, and therefore checked the progress of beasts and man across the Sahara into Central Africa; but this high ridge always remained well above the limits of such lakes, marshes, or inland seas. Tibesti was a well-watered region with at one time quite a heavy rainfall down to about twenty thousand years ago.

Before the war suspended such enterprises, the savants of France were exploring the wonderful sub-fossil remains of Algeria which revealed to us the existence there of a mammalian fauna resembling that of modern tropical Africa, of the region south of the Sahara. With that fauna were mingled in a very interesting degree creatures which at the present time are restricted to. India. For instance, there was something so like an Indian elephant that it might be called the Indian elephant, existing almost down to the human period in Algeria. There was a wild camel, an equine resembling a zebra ; there were gnus, hartebeests, oryxes, and other types of modern African antelopes ; and there was a Tragelaph allied to the Nilghai ; there was a huge buffalo with almost incredible horns-I4 feet long-incredible were it not that its existence is proved not only by its fossil remains but by the drawings of primitive man. The Foureau-Lamy Expedition, I believe, found many of the dry torrent-beds of the elevated Ahaggar region choked with hippopotamus bones. There is everything to point to quite a recent and rapid change in the climate of the Sahara, which, well within the human period, was a region abounding in water derived from a heavy rainfall, and richly endowed with forest areas, as we may see from the remains of petrified trees. This will bring home to you what gains might come to science and to our knowledge of the evolution of life on this planet if we could only thoroughly explore the Sahara, and above all such regions as the Tibesti highlands. 
Major Hanns VISCHER: Just after I had crossed the Sahara, some years ago, I had the great pleasure to meet Colonel Tilho in Nigeria ; arid last time we met-I think in I909-to celebrate our homecoming in Paris, we spoke of the work in Africa of our two respective countries. During my journey, and whenever I met the French in those regions, I was particularly impressed by the difficulties and privations these officers suffered so cheerfully. In Nigeria we had our railway, and we got frequent leave. As I remembered those isolated posts in the heart of the Sahara, while looking at the pictures we saw to-night, separated by hundreds of miles, rarely getting a mail or any provisions from the coast during those long years of war, when few boats went to the West Coast of Africa, I was filled with admiration for the work done by Colonel Tilho and his comrades. In the course of his lecture the Colonel showed clearly how necessary it is for us to co-operate in Africa, not only for the welfare of the native people but also for the very existence of our respective colonies. He has shown to us to-night how well we can complement each other. When that GermanTurkish column advanced south across the desert, at a moment when we had sent most of our troops from Nigeria to East Africa, it would have been a hard thing for the people in our colony if the officers under Colonel Tilho's orders, assisted by some native troops sent north from Nigeria, had not been able to arrest the enemy's progress.

The PREsident : I know you will all want me to congratulate Colonel Tilho on your behalf on the lucid, graceful, and humorous lecture he has given us this evening. There has been great talk about the co-operation between us and the French, and I think we might go a little deeper even than that. When we can get a French officer like Colonel Tilho over here in the flesh, and can hear from his own lips what he has done, when he shows us pictures of the kind of country he has had to make his way through, the kind of people he has had to make friends with : when we see all that, certainly we who have had to do similar work in other parts of the world-and probably you at home, even though you have not had that great pleasure and honour, must have a very deep fellow-feeling with him and his compatriots-we feel that there is something deep and common between us when we realize so vividly the work that they are doing, the difficulties that they have had to encounter, and the great work of civilization and humanization which they are carrying on in these far remote recesses of Central Africa. We have had to do the same things ourselves in other parts of the world. We see the results of our own efforts, and Colonel Tilho this evening has shown us what the French have done in opening out the great arid wastes of the Sahara desert and the French Sudan. What they have done and what we have done is good for the world as a whole. It has all been opened out gradually in the course of years, not only for the French and not only for the British, but for all nations. Therefore we here in England, we in this Society, will send forth a very hearty word of congratulation to the French, and especially to Colonel Tilho, for the great work which they are doing in Central Africa. He has made very important geographical discoveries, and has referred to new methods of geographical observation. Wireless telegraphy for the purpose of determining longitude is a comparatively new method, but one which is vastly valuable, because, as we who have tried to determine longitudes in far-away places know, in old days it was impossible to get the longitude at all exactly. We could get the latitude fairly accurately, within a few hundred yards, but longitude we could never get to within a few miles. Now by means of wireless telegraphy we are able to get longitude with almost complete exactitude, even in the heart 
of the French Sudan. Colonel Tilho has also made a slight allusion to another modern invention which I think in future will prove of great service, and that is the aeroplane. We shall hear more of that at our next meeting; but when you see those vast waterless regions, when you hear from Colonel Tilho of the enormous difficulty in getting across them with camels, then we see of what use the aeroplane might have been made for preliminary geographical reconnaissance. Those two inventions, I am certain, will be of enormous service to geography. I now wish on your behalf to tender to Colonel Tilho a most hearty vote of thanks for his lecture this evening, and also for his great kindness, at considerable personal inconvenience, in coming across from Paris to give us this paper.

\section{AN AIR-ROUTE RECONNAISSANCE FROM THE PACIFIC TO THE AMAZON}

\section{G. M. Dyott, late Squadron Commander, R.N.A.S.}

\section{Read at the Meeting of the Society, ig April r920.}

$\mathrm{M}^{\mathrm{v}}$ $\mathrm{Y}$ journeys in Northern Peru were not undertaken primarily with a view to acquiring geographical knowledge, although I must admit that it was lack of such information that made it necessary for me to travel as extensively as I did. The chief motive was to see if it was not possible to establish an aerial route that would connect the Pacific coast with the town of Iquitos, the inland port of Peru, situated some 2 I 47 miles up the Amazon. The net result of my observations was that no particular technical difficulties lay in the way of carrying out such a scheme; in fact, of all the world-routes which are being discussed at the present time, I think few offer less difficulties or greater advantages. Even if private capital could not be induced to inaugurate an air service through this wild part of the country, the Government itself could well afford to carry out the project simply as an insurance against loss of valuable territory, quite apart from any of the obvious commercial advantages which would be derived from it.

Now a transcontinental highway through this region has been discussed for many years, but the initial cost of a railway is tremendous, and a mountain trail is quite inadequate. The latest estimate submitted

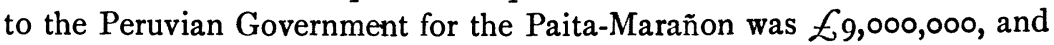
it was stated that as no return on the investment could be expected for twenty years, the State would have to guarantee 7 per cent. interest on the capital for that period. A rough estimate of outlay for an air service capable of making three trips every fortnight in either direction would be $\sum_{150,000}$. Furthermore, it would have this advantage, that when once the country had been explored, opened up, and settled, a railway could follow with some assurance of finding a sufficient volume of traffic at the commencement to justify a large capital expenditure.

The topographical configuration of Peru is peculiarly suitable for 